\title{
IMPLEMENTASI KEBIJAKAN ANGGARAN PENDAPATAN DAN BELANJA DESA DI DESA LOWIAN KECAMATAN MAESAAN KABUPATEN MINAHASA SELATAN
}

\author{
Johnetha Lafani Supit ${ }^{1}$, Grace B Nangoi ${ }^{2}$, Novi Budiarso ${ }^{3}$ \\ ${ }^{1,2,3}$ Fakultas Ekonomi dan Bisnis, Jurusan Akuntansi. Universitas Sam Ratulangi, Jl. Kampus Bahu Manado, \\ 95115, Indonesia \\ E-mail :lafanisupit@gmail.com
}

\begin{abstract}
The Indonesian Nation is part of the world community that has to participate in realizing a good government to support in the competition in the current era of globalization. Ministerial Regulation No. 113 of 2014 on the management of village finances. As referred to in Article 5 of the Minister of Home Affairs Number 113 of 2014 on preparing and implementing polices on the management of the Village Revenue and Expenditure Budget. Budget revenue and village spending is one of the things that must be considered to realize good governance in the village. The purpose of this study is to find out whether the implementation of revenue and expenditure budget policies runs well in accordance with Ministerial Regulation number 113 of 2014, and any constraints faced in implementing the policy of the village income and expenditure budget. The method used is qualitative descriptive method that is analyzing how the implementation of Village Revenue and Expenditure budget policy from planning to accountability. The result of the research show that the implementation of Village Revenue and Expenditure Budget policy in Lowian Village is good enough and has been in accordance with Ministerial Regulation No. 113 Year 2014 on the management of village finances but the problem is on the external side where the trees are located next to the road and plots of land owned by citizens, as well as village officials who still do not really understand the technical reporting-making
\end{abstract}

Keywords: Policy Implementation, Accountability, Village Revenue and Expenditure Budget

\section{PENDAHULUAN}

Era globalisasi saat ini Bangsa Indonesia merupakan bagian dari masyarakat dunia yang memiliki kewajiban untuk secara terus-menerus berpartisipasi dalam mewujudkan pemerintahan yang baik (good governance) untuk menunjang dalam persaingan di era globalisasi. Keberadaan otonomi daerah pada saat ini membawah suatu hal baru bagi Pemeritah Daerah dimana daerah menjadi semakin mandiri dalam hal pelaksanaan kegiatan pemerintahan maupun pembangunan di masing-masing daerah. Pemberian otonomi di arahkan juga untuk mempercepat terwujudnya kesejahteraan dan pelayanan kepada masyarakat. Keberadaan otonomi daerah pada saat ini membawah suatu hal baru bagi Pemeritah Daerah dimana daerah menjadi semakin mandiri dalam hal pelaksanaan kegiatan pemerintahan maupun pembangunan di masing-masing daerah. Pemberian otonomi di arahkan juga untuk mempercepat terwujudnya kesejahteraan dan pelayanan kepada masyarakat (Akonji et al, 2013) Otonomi daerah dilancarkan sejak 1 januari 2001, dimana daerah-daerah otonom (Kabupaten/Kota) deberi kewenangan untuk mengatur dan mengurus rumah tangganya sesuai aspirasi dari masyarakat dan tidak bertentangan dengan peraturan perundang-undangan yang berlaku.

Bicara soal tujuan otonomi yang memungkinkan daerah untuk mandiri dan berdaya guna serta berhasil mensejahtrakan masyarakat. Desa merupakan wilayah yang memiliki hak otonom untuk mengatur dan meningkatkan pembangunannya sendiri untuk meningkatkan 
kesejahteraan masyarakat. Seiring dengan perkembangan otonomi daerah, pemerintah pusat yang memberikan tugas pembantuan kepada pemerintah desa harusnya selalu memperhatikan dan menekankan pembangunan masyarakat desa melalui otonomi pemerintahan desa dan peran aktif serta partis ipasi masyarakat dalam pembangunan desa.

Diterbitkanya Perturan Mentri Dalam Negeri No. 113 tahun 2014 tentang pengelolaan keuangan desa yang memberikan landasan bagi otonomi desa secara praktik bukan hanya sekedar normatif, Oleh karena itu, Pengelolaan keuangan desa merupakan keseluruhan kegiatan yang meliputi perencanaan, penganggaran, penatausahaan, pelaporan pertanggungjawaban, sampai dengan pengawasan pengelolaan tersebut. Implementasi Kebijakan Anggaran pendapatan dan belanja desa sangat terkait dengan penelitian tentang Anggaran Pendapatan dan Belanja Desa (APBDes). Anggaran Pendapatan Dan Belanja Desa (APBDes) adalah instrumen penting yang sangat menentukan terwujudnya tata pemerintahan yang baik di Desa. Anggaran Pendapatan dan Belanja Desa terkait dengan penelitian ini maka Implementasi Kebijakan dalam penggunaan APBDes seharusnya bejalan baik dan juga anggaran harus sesuai prioritas kebutuhan dan tepat sasaran terhadap kepentingan publik. Berdasarkan uraian latar belakang, maka rumusan masalah dalam penelitian ini adalah :

1. Bagaimana Implementasi Kebijakan Anggaran Pendapatan dan Belanja Desa di Desa Lowian Kecamatan Maesaan?

2. Apa Kendala Dalam Mengimplementasi Kebijakan Anggaran Pendapatan dan Belanja Desa di Desa Lowian Kecamatan Maesaan?

Berdasarkan rumusan masalah yang ada, tujuan dilakukannya penelitian ini adalah untuk mengetahui:

1. Implementasi Kebijakan Anggaran Pendapatan dan Belanja Desa berjalan dengan baik sesuai dengan Peraturan Mentri Dalam Negeri (Permendagri) Nomor 113 Tahun 2014.

2. Kendala-kendala apa yang dihadapi dalam Implementasi Kebijakan Anggaran Pendapatan dan Belanja Desa di Desa Lowian Kecamatan Maesaan.

\section{TINJAUAN PUSTAKA}

\subsection{Teori Implementasi Kebijakan}

Implementasi Kebijakan sebagai tindakan yang dilakukan oleh publik maupun swasta baik secara individu maupun kelompok yang ditunjukan untuk mencapai tujuan yang telah ditetapkan dalam keputusan kebijakan (Safawi et al., 2012:132). Sehinggah implementasi kebijakan sangat diperlukan karena pada tahap itulah dapat dilihat kesesuaian berbagai faktor determinan keberhasilan implementasi kebijakan atau program (Akib, 2010:4). Karena konsistensi implementasi kebijakan nasional menentukan keberhasilan dan kegagalan suatu bangsa (Nugroho, 2014:53).

\subsubsection{Langkah-langkah Implementasi Kebijakan}

Nugroho (2014:243) merumuskan menjadi tiga langkah dengan tujuan agar implementasi akan berjalan sebelum mulai mengimplementasikannya. Adapun langkahlangkah Penerimaan Kebijakan, Adopsi Kebijakan, dan Kesiapan Strategi.

\subsubsection{Faktor-faktor Implementasi Kebijakan}

Menurut Edward III yang dikutip Subarsono (2010) ada emapt variabel yang memepengaruhi factor dari implementasi kebijakan yakni; Komunikasi, Sumberdaya, Disposisi, dan Struktur Birokrasi. 


\subsection{Konsep Akuntansi}

Menurut Sadeli (2015:2) menyatakan bahwa akuntansi digunakan untuk mencatat, meringkas, melaporkan, menginterpretasikan data dasar ekonomi untuk kepentingan perorangan, pengusaha, pemerintah, dan anggota masyarakat lainnya.

\subsubsection{Akuntasi Sektor Publik}

Menurut Rondonuwu (2015:23), Akuntansi sektor publik di indonesia pada berbagai yakni sebagai berikut :

1. Akuntansi pusat

2. Akuntansi pemerintahan

3. Akuntansi Desa

4. Akuntansi Tempat Ibadah : Masjid, Gereja, Pura, Wihara

5. Akuntansi LSM

6. Akuntansi Yayasan

7. Akuntansi Pendidikan : Sekolah, Perguruan Tinggi

8. Akuntansi Kesehatan : Puskesmas, Rumah Sakit

\subsubsection{Akuntansi Pemerintahan}

Menurut Dedi (2012:1) Akuntansi pemerintahan adalah aplikasi akuntansi di bidang keuangan negara (Public Finance), Khususnya pada tahapan pelaksanaan anggaran (Butget execution), termasuk yang di timbulkannya, baik yang bersifat seketika maupun yang lebih permanen pada semua tingkatan dan unit pemerintahan, tuntutan transparansi dan akuntabilitas publik atas penggunanaan akuntansi dalam mencatan dan melaporkan kinerja pemerintahan.

\subsubsection{Akuntansi Desa}

Menurut Rusmianto \& Yuliansyah (2016 : 5) Menyatakan Akuntansi Desa juga berperan dalam penyusunan Anggaran Pendapatan dan Belanja Desa (APBDes), Hal itu di pertegas dengan adanya keharusan untuk menyusun APBDes yang di jelaskan dalam Peraturan Mentri Dalam Negri (Permendagri) Nomor 113 Tahun 2014 Tentang Pengelolaan Keuangan Desa. Dengan adanya kewenangan pengelolan keuangan tersebut, maka secara hukum Pemerintah Desa wajib untuk melaporkan kinerja kepada pemerintah dan masyarakat untuk menunjukan transparansi suatu laporan Pemerintah Desa.

\subsubsection{Pengelolaan Keuangan Daerah}

Menurut Pajouw (2015) Pengelolaan keuangan daerah harus dikelola secara tertib, taat pada peraturan Perundang-undangan, efektif, efisien, ekonomis, transparan, dan bertanggungjawab dengan memperhatikan azas keadilan, kepatuhan, dan manfaat untuk masyarakat. Salah satunya upaya konkrit untuk mewujudkan transparansi dan akuntabilitas pengelolaan keuangan daerah adalah penyampain laporan pertanggungjwaban keuangan pemerintah yang memenuhi prinsip tepat waktu dan dapat diandalkan (Reliable) serta disusun dengan mengikuti satandar akuntansi yang berlaku.

\subsection{Desa dan Pemerintahan Desa}

Menurut Nurcholis (2011) diartikan sebagai penyelenggaraan Pemerintah Desa merupakan subsitensi dari sistem penyelenggaraan Pemerintah, sehingga Desa memilikin kewenangan untuk mengurus dan mengatur kepentingan masyarakat. Kepala desa bertanggung jawab kepada badan permusyawaratan Desa dan menyampaikan laporan pelaksanaan tersebut kepada Bupati. 


\subsubsection{Anggaran Pendapatan dan Belanja Desa (APBDes)}

Menurut Hasan (2015 :3) menyatakanAnggaran Pendapatan dan Belanja Desa atau APBDes adalah perturan desa yang memuat sumber-sumber penerimaan dan alokasi pengeluaran desa dalam kurun waktu satu tahun. APBDesa terdiri atas bagian Pendapatan Desa, Belanja Desa, dan Pembiayaan. Rancangan APBDes di bahas dalam musyawarah perencanaan pembangunan desa.

\subsubsection{Struktur Anggran Pendapatan dan Belanja Desa}

Menurut Lapananda (2016) Pengaturan mengenai struktur Anggaran Pendapatan dan Belanja Desa atau yang di singkat dengan APBDes, diatur dalam pasal 8 hingga pasal 19 peraturan Mentri Dalam Negeri Nomor 113 Tahun 2014 tentang Pengelolaan Keuangan Desa. Selain itu, APBDesa Diberi pengertian sebagai rencana keuangan tahunan Pemerintah Desa. Adapun struktur APBDes terdiri atas; Pendapatan Desa, Belanja Desa, Pembiayaan Desa

\subsubsection{Pelaksanaan Anggaran Pendapatan dan Belanja Desa}

Pengaturan mengenai pelaksanaan APBDes, diatur dalam pasal 24 hingga 34 Permendagri Nomor 113 Tahun 2014 tentang Pengelolaan Keuangan Desa. Semua penerimaan dan pengeluaran desa dalam rangka pelaksanaan kewenangan desa dilaksanakan melalu rekening kas desa. Rekening Kas Desa adalah rekening tepat menyimpan uang Pemerintah Desa yang menampung seluruh penerimaan desa dan digunakan untuk membayar selurung pengeluaran Desa pada Bank yang ditetapkan.

\subsubsection{Pelaporan Pertaggungjawaban Pelaksanaan Anggaran Pendapatan dan Belanja desa}

Visi Media (2016) Pengaturan mengenai pelaporan dan pertanggungjawaban pelaksanaan ABPDes, diatur dalam pasal 103 dan pasal 104 Peraturan Pemerintah No. 43 Tahun 2014 tentang Peraturan Pelaksanaan Undang-undang Nomor 6 Tahun 2014 tentang Desa, dan pasal 37 hingga pasal 42 Peraturan Menteri Dalam negeri Nomor 113 Tahun 2014 tentang Pengelolaan Keuangan Desa. Siklus pengelolaan keuangan desa pelaporan dan pertanggungjawaban merupakan bagian akhir dari siklus pengelolaan keuangan desa, selain perencanaan, pelaksanaan dan penatausahaan. Laporan yang dimaksud adalah laporan realisasi pelaksanaan APBDes dan laporan pertanggungjawaban realisasi pelaksanaan APBDes.

\subsubsection{Pengelolaan Keuangan Desa}

Menurut Caro (2015) Pengelolaan Keuangan Desa adalah keseluruhan kegiatan yang meliputi perencaan, pelaksanaan, penatausahaan, pelaporan, dan pertanggungjawaban keuangan desa. Penyelenggaraan kewenangan Desa yang di tugaskan oleh Pemerintah didanai oleh anggaran pendapatan dan belanja negara. Dana anggranpendapatan dan belanja negara dialokasikan pada bagian anggaran kementrian/lembaga dan disalurkan melalui satuan kerja perangkat daera (SKPD) kabupaten/kota.

\subsubsection{Asas Pengelolaan Keuangan Desa}

Menurut Wenny (2012) Asas adalah nilai-nilai yang menjiwai pengelolaan keuangan Desa. Asas yang dimaksud melahirkan prinsip yang menjadi dasar dan harus tercermin dalam setiap tindakan pengelolaan keuangan Desa. Asas dan prinsip tidak berguna bila tidak terwujud dalam tindakan. Sesuai Permendagri No. 113 Tahun 2014 Keuangan Desa dikelola berdasarkan asas-asas yaitu; Asas Transparan, Asas Akuntabel, Asas Partisipatif, Asas Tertib dan Disipin Anggaran. 


\subsubsection{Organisasi Pengelolaan Keuangan Desa}

Menurut Nurman (2015), organisasi Pengelolaan Keuangan terdiri dari Kepala Desa, PTKD/Pelaksana Teknis Pengelolaan Keuangan Desa, Sekertaris Desa, Kepala Seksi, dan Bendahara Desa.

\subsection{Penelitian Terdahulu}

1. Edita Erlina Rujiman (2014) dalam penelitian yang berjudul Peranan Anggaran Pendapatan dan Belanja Desa Dalam Pembangunan Wilayah Perdesaan Di Kabupaten Serdang Bedagai. Tujuan dari penelitian ini adalah untuk menganalisisi peran APBDesa dalam pembangunan wilayah perdesaan di kabupaten serdang bedagai. Hasil dari penelitian ini menunjukan bahwa APBDesa memainkan peran penting dalam pembangunan perdesaan di desa Firdaus,Kecamatan Sei Rampah, Serdang Bedagai.

2. Didik Fakthur Rohman (2013) dalam penelitian yang berjudul Implementasi Kebijakan Pelayanan Administrasi Kependudukan Terpadu (Studi pada Dinas Kependudukan dan Catatan Sipil Kota Malang). Tujuan dari penelitian ini adalah Menganalisis implementasi kebijakan pelayanan administrasi kependudukan secara terpadu dalam memberikan pelayanan kepada masyarakat di Dinas Kependudukan dan Catatan Sipil Kota Malang dan Menganalisis factor pendukung dan penghambat. Hasil penelitian ini menunjukan Kebijakan sentralisasi pengurusan kartu tanda penduduk merupakan langkah maju Pemerintah Kota Malang terutama dalam bidang pelayanan publik untuk merapikan sistem administrasi kependudukan.

\section{METODE PENELITIAN}

\subsection{Jenis Data}

Dalam penelitian ini penulis menggunakan Data kualitatif yang bersifat deskriptif, untuk mengetahui atau menggambarkan keyataan dari kejadian yang di teliti sehingga memudahkan penulis untuk mendapatkan data yang objektif dalam rangka memahami Implementasi Kebijakan APBDes di Desa Lowian. Data kualitatif yang digunakan dalam penelitian ini yaitu berupa gambaran umum objek penelitian dan data tentang implementasi kebijakan anggaran pendaptan dan belanja desa di desa lowian. Penulis juga dalam penelitian ini menggunakan penelitian kulatiatif, karena permasalahan berhubungan dengan manusia yang secara fundamental bergantung pada pengamatan.

\subsection{Tempat dan Waktu Penelitian}

Lokasi penelitian yang dilaksanakan di Desa Lowian Kecamatan Maesaan Kabupaten Minahasa Selatam. Waktu Penelitian yang dilaksanakan bulan Agustus 2017 sampai selesai.

\subsection{Sumber Data}

Data yang digunakan dalam penelitian ini meliputi :

1. Data Primer : Merupakan data yang diperoleh dengan cara melakukan penelitian langsung ke lapangan guna memperoleh atau mengumpulkan keterangan untuk selanjutnya diolah sesuai dengan kebutuhan peneliti (Sugiono 2016)

Dalam penelitian ini, data primer yang digunakan adalah data yang diperoleh dengan cara melakukan penelitian langsung ke lapangan dengan melakukan wawancara dalam hal ini data laporan pertanggungjawaban APBDes Tahun Anggaran 2016. 
2. Data Sekunder : Merupakan data yang diperoleh secara langsung dari instansi/objek penelitian melalui arsip-arsip dan dokumen-dokumen dari instansi yang bersangkutan (Sugiono 2016).

Dalam penelitian ini penulis menggunakan Data Primer dan Data Sekunder dengan cara meneliti secara langsung agar mendapatkan hasil data yang baik dalam mendukung penelitian ini.

\subsection{Prosedur Penelitian}

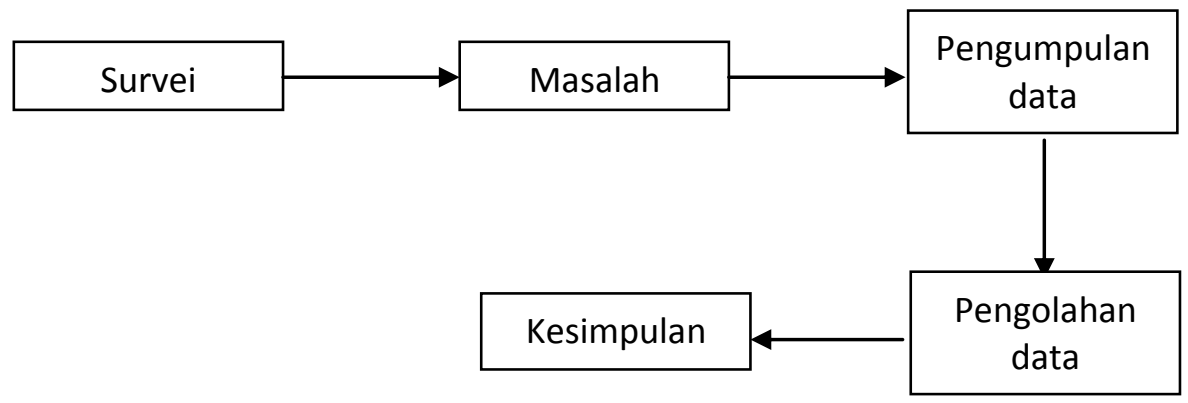

1. Survei langsung ke objek penelitian di Desa Lowian dengan wawancara.

2. mengevaluasi masalah yang ada di objek tersebut.

3. Mengumpulkan data yang di ambil dari Desa.

4. Mengolah data yang sudah di ambil lalu di teliti bagaimana implementasi kebijakannya.

5. Pengambilan kesimpulan dan saran

\subsection{Metode Pengumpulan Data}

Teknik yang digunakan dalam pengumpulan data adalah melalui penelitian ke Desa Lowian Kecamatan Maesaan melalui wawancara langsung yang dilakukan dengan melakukan tanya-jawab dengan pihak-pihak yang terkait yaitu dengan Kepala Seksi BPD ( Badan Permusyawaratan Desa ) dan bagian Pemerintah Desa yang ada di Desa dan penelusuran terhadap dokumen-dokumen yang mendukung penelitian ini.

\subsection{Metode Analisis Data}

Metode analisis yang digunakan untuk membahas permasalahan ini adalah dengan menggunakan metode analisis deskriptif, yaitu analisis permasalahan yang sifatnya menguraikan, menggambarkan dan melukiskan suatu data atau keadaan sedemikian rupa sehingga dapat ditarik suatu kesimpulan untuk menjawab permasalahan yang ada yaitu mengenai implementasi kebijakan anggaran pendapatan dan belanja desa. Teknik Analisis Data yang digunakan dalam penelitian ini adalah:

1. Menganalisis kebijakan Anggaran Pendapatan dan Belanja Desa di Desa Lowian.

2. Menganalisis pelaksanaan Anggaran Pendapatan dan Belanja Desa di Desa Lowian.

3. Menarik kesimpulan dan memberikan saran untuk dijadikan bahan masukan bagi pemerintahan/aparatur desa Lowian.

\section{HASIL PENELITIAN DAN PEMBAHASAN}

\subsection{Gambaran Umum Objek Penelitian}

Demografi Desa Lowian secara administratif berada di Kecamatan Maesaan Kabupaten Minahasa Selatan. dibagian Utara berbatasan dengan Desa Sion, dibagian Timur berbatasan dengan desa Tumani, di Selatan berbatasan dengan desa Tambelang sedangkan di 
sebelah Barat berbatasan dengan Desa Temboan. Posisi yang berada di ketinggian rata-rata $750 \mathrm{Mdpl}$ menjadikan suhu udara yang sejuk antara $25-30^{\circ} \mathrm{C}$ dan dapat mencapai hingga $14^{\circ}$ $\mathrm{C}$ saat subuh. Kondisi wilayah berbukit-bukit dan sebagian kecil dataran dengan luas \pm 717 Ha.Yang dibagi dalam system pemerintahan menjadi empat jaga.Luas pemukiman $\pm 97 \mathrm{Ha}$ serta luas lahan sawah teririgasi teknis seluas 210 Ha. Desa Lowian dengan luas wilayah $4.040 \mathrm{M}^{3}$ terbagi dalam empat wilayah jaga.

\subsection{Hasil Penelitian}

4.2.1 Implementasi Kebijakan Anggaran Pendapatan dan Belanja Desa di Desa Lowian Kecamatan Maesaan Kabupaten Minahasa Selatan

1. Pengelolaan Anggaran Pendpatan Dan Belanja Desa (APBDesa)

Gambar 4.2

Kerangka Petunjuk Teknis (Juknis) APBDes

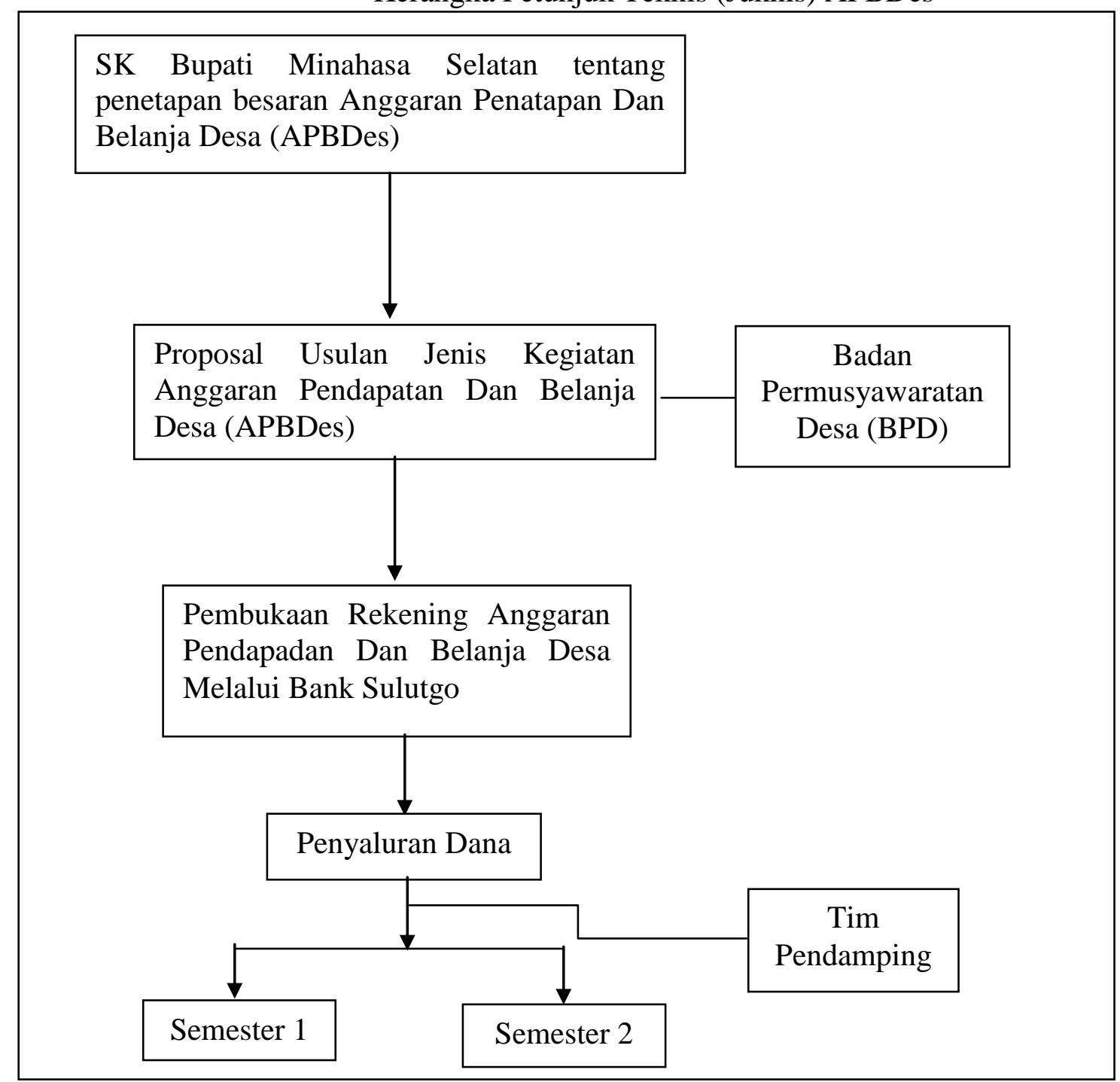

Sumber : Dinas PMD Kabupaten Minahasa Selatan

Setelah ranperdes tentang APBDesa disusun oleh Sekertaris Desa dan selanjutnya disampaikan oleh Kepala Desa kepada BPD untuk dibahas dan disepakati bersama setelah melalui evaluasi oleh Bupati/Walikota atau camat maka ranperdes tentang APBDesa ditetapkan menjadi peraturan desa tentang APBDesa. Selanjutnya APBDesa mulai 
dilaksanakan pada tanggal 1 januari sampai dengan 31 Desember, pengaturan mengenai pelaksanaan APBDesa, diatur dalam pasal 24 hinga pasal 34 peraturan Menteri Dalam Negeri Nomor 113 Tahun 2014 tentang Pengelolaan Keuangan Desa.

1. Desa dalam hal ini diwajibkan membuat proposal usulan jenis kegiatan sesuai dengan kebutuhan masing-masing desa yang mengacu dalam petujuk teknis tentang besaran dan Anggaran Pendapatan Dan Belanja Desa yang ditandatangani oleh Hukum Tua, mengetahui camat setempat dan Kepala Dinas Pemberdayaan Masyarakat dan Pemrintah Desa Kabupaten Minahasa, diteliti oleh Kepala Dinas Pemberdayaan masyarakat Desa (PMD), dan menyetujui atas nama Bupati Minahasa Asisten Pemeritahan dan Kesejahteraan Rakyat.

2. Setelah proposal usulan jenis kegiatan telah disetujui, maka Hukum Tua dan Bendahara Desa diharuskan untuk membuka rekening sebagai tempat ditrasfernya dana.

3. Selanjatunya penyaluran dana APBDesa dilakukan dalam 2 (dua) semester, yaitu semester I sebesar dan semester II sebesar.

4. Penyaluran tahap II dilakukan setelah Tim Fasilitasi APBDes Tingkat Kabupaten melakukan monitoring lapangan, didampingi Tim Pendamping Kecamatan berdasarkan laporan pelaksanaan APBDesa tahap I di Desa.

5. Tim Pendamping Tingkat Kecamatan diangkat dari Perangkat Kecamatan yang deketuai oleh Camat dan beranggotakan unsur-unsur antara lain : Kepala Seksi Badan Pemberdayaan Masyarakat Desa (PMD) dan Kepala Seksi Pemerintahan, serta ditetapkan berdasarkan Surat Penunjukan Camat.

6. Tim Pelaksanaan Tingkat Desa dipilih dari perangkat Desa, diangkat dan ditetapkan oleh Hukum Tua berdasarkan Surat keputusan Hukum Tua, dengan susunan sebagai berikut: Hukum Tua selaku Penanggungjawab pengendali, Ketua selaku penanggungjawab teknis kegiatan, dan Bendahara selaku penanggungjawab administrasi/keuangan.

2. Perencanaan dan Penganggaran Keuangan Desa

1. Perencanaan Keuangan Desa

Pemerintah Desa menyusun perencanaan pembangunan desa sesuai dengan kewenangannya dengan mengacu pada perencanaan pembangunan kabupaten/kota. Perencanaan Pembangunan Desa meliputi RPJMDes dan RKPDes yang disusun secara berjangka dan ditetapkan dengan Peraturan Desa. Rencana Pembangunan Jangka Menengah Desa (RPJMDes) untuk jangka waktu 6 (enam) tahun sedangkan Rencana Pembangunan Tahunan Desa atau yang disebut Rencana Kerja Pemerintah Desa (RKPDes) untuk jangka waktu 1 (satu) tahun. RKPDes merupakan penjabaran dari Rencana Pembangunan Jangka Menengah Desa. Perencanaan pembangunan desa disusun berdasarkan hasil kesepakatan dalam musyawarah desa yang pelaksanaannya paling lambat pada bulan Juni tahun anggaran berjalan. Rencana Pembangunan Jangka Menengah Desa (RPJMDes) dalam menyusun RPJMDes, pemerintah desa wajib menyelenggarakan Musyawarah Perencanaan Pembangunan Desa (Musrenbangdes) secara partisipatif. Musrenbangdes diikuti oleh pemerintah desa, Badan Permusyawaratan Desa dan unsur masyarakat desa, yang terdiri atas tokoh adat, tokoh agama, tokoh masyarakat dan/atau tokoh pendidikan. RPJMDes ditetapkan dalam jangka waktu paling lama 3 (tiga) bulan terhitung sejak tanggal pelantikan kepala desa.

\section{Proses Penganggaran}

Setelah RKPDes ditetapkan maka dilanjutkan proses penyusunan APBDes. Rencana Kegiatan dan Rencana Anggaran Biaya yang telah ditetapkan dalam RKPDes dijadikan pedoman dalam proses penganggarannya. Anggaran Pendapatan dan Belanja Desa (APBDes) 
merupakan rencana anggaran keuangan tahunan pemerintah desa yang ditetapkan untuk menyelenggarakan program dan kegiatan yang menjadi kewenangan desa. Proses Penyusunan APBDes dimulai dari Pelaksana Kegiatan menyampaian usulan anggaran kegiatan kepada Sekretaris Desa berdasarkan RKPDes yang telah ditetapkan; Sekretaris Desa menyusun rancangan Peraturan Desa tentang APBDes (RAPBDes) dan menyampaikan kepada Kepala Desa; Kepala Desa selanjutnya menyampaikan kepada Badan Permusyawaratan Desa untuk dibahas dan disepakati bersama. Rancangan Peraturan Desa tentang APBDes disepakati bersama paling lambat bulan Oktober tahun berjalan antara Kepala Desa dan BPD; Rancangan Peraturan Desa tentang APBDes yang telah disepakati bersama sebagaimana selanjutnya disampaikan oleh Kepala Desa kepada Bupati/Walikota melalui camat atau sebutan lain paling lambat 3 (tiga) hari sejak disepakati untuk dievaluasi; Bupati/Walikota menetapkan hasil evaluasi Rancangan APBDes paling lama 20 (dua puluh) hari kerja sejak diterimanya Rancangan Peraturan Desa tentang APBDes. Dalam hal Bupati/Walikota tidak memberikan hasil evaluasi dalam batas waktu maka Peraturan Desa tersebut berlaku dengan sendirinya. Dalam hal Bupati/Walikota menyatakan hasil evaluasi Rancangan Peraturan Desa tentang APBDes tidak sesuai dengan kepentingan umum dan peraturan perundang-undangan yang lebih tinggi Kepala Desa melakukan penyempurnaan paling lama 7 (tujuh) hari kerja terhitung sejak diterimanya hasil evaluasi. Apabila hasil evaluasi tidak ditindak lanjuti oleh Kepala Desa dan Kepala Desa tetap menetapkan Rancangan Peraturan Desa tentang APBDes menjadi Peraturan Desa; Peraturan Desa tentang APBDes ditetapkan paling lambat tanggal 31 Desember tahun anggaran berjalan. Bupati/walikota dalam melakukan evaluasi Rancangan Peraturan Desa tentang APBDes dapat mendelegasikan kepada camat. Ketentuan lebih lanjutmengenai pendelegasian evaluasi Rancangan Peraturan Desa tentang APBDesa kepada Camat diatur dalam Peraturan Bupati/Walikota. Penyusunan APB Desa sebagaimana telah diuraikan diatas memiliki batasan waktu yang diatur dalam peraturan perundangan.

\section{Pelaksanaan Kebijakan Keuangan Desa}

Dalam pembuatan Anggaran Pendapatan dan Belanja Desa (APBDes) harus mempunyai implementasi mekanisme penyusunan yang baik. Mekanisme implementasi yang dimaksud yaitu alur-alur dalam pembuatan APBDes itu sendiri. Karena dalam proses penysusnan APBDes, harus meluputi pelaksanaan keuangan desa sampai pada pertanggungjawaban keuangan desa agar anggaran atau dana yang ditetapkan dalam permusyawaratan desa dapan berjalan dengan baik dan tepat sasaran. Dalam pelaksanaan APBDes di perlukan belanja agar pelaksanaan kebijakan APBDes dapat berjalan dengan baik. Klasifikasi Belanja berdasarkan jenis terdiri dari Belanja Pegawai, Belanja Barang/Jasa, dan Belanja Modal.

1) Belanja Pegawai

Belanja Pegawai dianggarkan untuk pengeluaran penghasilan tetapdan tunjangan bagi Kepala Desa dan Perangkat Desa serta tunjangan BPD yang pelaksanaannya dibayarkan setiap bulan. Belanja Pegawai tersebut dianggarkan dalam kelompok Penyelenggaraan Pemerintahan Desa, dengan kegiatan Pembayaran Penghasilan Tetap danTunjangan.

2) Belanja Barang dan Jasa

Belanja Barang dan Jasa digunakan untuk pengeluaran pembelian/ pengadaan barang yang nilai manfaatnya kurang dari 12 (dua belas) bulan.

3) Belanja Modal

Belanja Modal digunakan untuk pengeluaran dalam rangka pembelian /pengadaan barang atau bangunan yang nilai manfaatnyalebih dari 12 (dua belas) bulan yang digunakan untuk kegiatan penyelenggaraan kewenangan desa. Contoh Belanja Modal adalah 
Pembangunan Jalan Desa, Pembangunan Jembatan Desa, Pengadaan Komputer, Pengadaan Meublair dan lain sebagainya.

4. Pelaporan dan Pertanggungjawaban Keuangan Desa

Dalam melaksanakan tugas, kewenangan, hak, dan kewajibannya dalam pengelolaan keuangan desa, kepala desa memiliki kewajiban untuk menyampaikan laporan. Laporan tersebut bersifat periodik semesteran dan tahunan, yang disampaikan ke Bupati/Walikota dan ada juga yang disampaikan ke BPD. Laporan kepada Bupati/Walikota (melalui camat) yaitu; Laporan Semesteran Realiasasi Pelaksanaan APBDes. Laporan Pertanggungjawaban Realisasi Pelaksanaan APBDes kepada Bupati/Walikota setiap akhir tahun anggaran. Laporan Realisasi Penggunaan Dana Desa. Laporan kepada Badan Permusyawaratan Desa (BPD). Laporan Keterangan Pertanggungjawaban Realisasi Pelaksanaan APB DesaTerdiri dari Pendapatan, Belanja, dan Pembiayaan.

1. Laporan Realisasi Pelaksanaan APBDes

Laporan Realiasasi Pelaksanaan APBDes disampaikan kepada Bupati/Walikota melalui camat, terdiri dari; Laporan Semester Pertama, disampaikan paling lambat pada akhir bulan Juli tahun berjalan. Laporan Semester Akhir Tahun, disampaikan paling lambat pada akhir bulan Januari tahun berikutnya. Laporan Realisasi Pelaksanaan APB Desa Semester Pertama menggambarkan realisasi pendapatan, belanja dan pembiayaan selama semester I dibandingkan dengan target dan anggarannya, sedangkan Laporan Realisasi Pelaksanaan APBDesa Semester Akhir Tahun mengambarkan Realisasi pendapatan,belanja dan pembiayaan sampai dengan akhir Tahun, jadi bersifat akumulasi hingga akhir tahun anggaran.

2. Laporan Realisasi Penggunaan Dana Desa

Laporan Realisasi Penggunaan Dana Desa disampaikan kepadabupati /walikota setiap semester. Penyampaian laporan realisasi penggunaan Dana Desa dilakukan. Untuk semester I paling lambat minggu keempat bulan Juli tahun anggaran berjalan. Untuk semester II paling lambat minggu keempat bulan Januari tahun anggaran berikutnya. Berdasarkan Laporan Dana Desa dari desa-desa yang ada di wilayah kabupaten/kota, Bupati/Walikota menyampaikan Laporan Realisasi Penyaluran dan Konsolidasi Penggunaan Dana Desa kepada Menteri keuangan dengan tembusan menteri yang menangani desa, menteri teknis/pimpinan lembaga pemerintah nonkementerian terkait, dan gubernur paling lambat minggu keempat bulan Maret tahun anggaran berikutnya. Sampai dengan panduan ini selesai disusun, belum ada ketentuan yang mengatur tentang format Laporan Dana Desa yang harus disampaikan oleh desa dan format kompilasi yang harus disusun oleh pemerintah kabupaten/kota. Yang bisa menjadi acuan dalam pengelolaan dana desa adalah Peraturan Menteri Desa, PDT dan Transmigrasi Nomor 5 Tahun 2015 tentang Prioritas Penggunaan Dana Desa Tahun 2015. Hal yang perlu menjadi perhatian terkait penggunaan Dana Desa adalah SiLPA Dana Desa. Bupati/walikota memberikan sanksi administrasi berupa pengurangan Dana Desa jika SilPA-nya tidak wajar ( $\pm 30 \%)$, yang dikarenakan penggunaan tidak sesuai dengan prioritas atau penyimpanan uang dalam bentuk deposito lebih dari 2 (dua) bulan.

3. Laporan Pertanggungjawaban Realisasi Pelaksanaan APBDes

Laporan Pertanggungjawaban Realisasi Pelaksanaan APBDes merupakanlaporan yang disampaikan secara periodik kepada BPD terhadap pelaksanaan APBDes yang telah disepakati di awal tahun dalam bentuk Peraturan Desa. Rancangan Peraturan Desa tentang Pertanggungjawaban Realiasi Pelaksanaan APBDes tidak dilakukan evaluasi sebagaimana proses peraturan desa untuk penetapan APBDes. Hal ini didasarkan pada Permendagri Nomor 111 Tahun 2014 tentang Pedoman Teknis Peraturan diDesa pada pasal 14 dimana dinyatakan hanya 4 (empat) jenis Rancangan Peraturan Desa yang telah dibahas dan 
disepakati oleh Kepala Desa dan BPD yang dilakukan evaluasi oleh Bupati/Walikota melalui camat yaitu tentang; APBDes, Pungutan, Tata Ruang, dan Organisasi Pemerintah Desa. Laporan ini disampaikan kepada BPD secara tertulis paling lambat 3 (tiga)bulan setelah berakhirnya tahun anggaran (PP 43/2014 pasal 51).

\subsubsection{Kendala-kendala Dalam Implementasi Kebijakan Anggaran Pendapatan dan Belanja Desa di Desa Lowian Kecamatan Maesaan Kabupaten Minahasa Selatan}

1. Komunikasi

Dalam penyapaian implementasi kebijakan anggaran pendapatan dan belanja desa sudah jelas sehingga masyarakat sudah mengerti dan tahu atas adanya pelaksanaan anggaran pendapatan dan belanja desa di desa lowian. Aparatur desa juga sudah memberikan pemahaman kepada masyarakat tentang adanya APBDes walaupun dalam kenyataannya masih banyak masyarakat yang juga belum terlalu paham akan adanya APBDes dan Implementasinya terhadap desa itu sendiri. Oleh karena itu satu dari tiga hal dalam komunikasi sepenuhnya belum sesuai yaitu, penyaluran yang belum baik sehingga akan menghasilkan implementasi yang belum baik pula, adanya kejelasan yang diterima oleh pelaksana kebijakan sehingga tidak membingungkan dalam pelaksanaan kebijakan, dan adanya konsistensi yang diberikan dalam pelaksanaan kebijakan.

2. Sumber Daya

Dalam implementasi kebijakan harus ditunjang oleh sumberdaya baik sumberdaya manusia, materi, dan metoda. Dalam sumber daya lah terdapat masalah, terutama dalam sumber daya manusia yang dimana masih ada aparatur yang belum mengerti dan memahami akan pembuatan Laporan Pertanggung Jawaban dikarenakan kualitas aparaturnya sendiri yang tergolong rendah, Pendidikan yang juga masih rendah dikarenakan Pendidikan yang ditempuh hanya Pendidikan standar yang hanya wajib sekolah 9 (Sembilan) sampain 12 tahun. Factor usia yang juga mempengaruhi akan pembuatan laporan pertanggungjawaban yang dimana aparatur desa kurang bisa menghafal atau mengingat kode rekening itu sendiri. sehingga itu sumber daya manusia dalam hal ini sangat mempengaruhi kendala yang terjadi dalam pelaporan pertanggungjawaban.

3. Disposisi

Disposisi dalam hal ini sudah berjalan dengan baik karena aparatur desa sendiri dalam mengimplementasi kebijakan APBDes dengan komitemen untuk memajukan desa Lowian agar tidak tertinggal dengan desa lain-lain yang ada disektiar Sulawesi Utara terlebih khusus di Minahasa Selatan. Dalam hal kejujuran juga sudah sesuai diakarenakan setiap ada kegiatan selalu diberitahukan kepada masyarakat agar masyarakat tahu dan menunjukan transparansi. Dalam sifat demokratis juga telah sesuai dengan semestinya, karena dalam memutuskan sesuatu aparatur desa juga selalu memusyawarakan dengan masyarakat agar tidak terjadi salah pengertian antar masyarakat dan aparatur desa. Sehingga disposisi dalam hal ini sepenuhnya sudah berjalan dengan baik sesuai dengan semestinya.

4. Struktur Birokrasi

Pada sturuktur birokrasi sudah sesuai dikarenakan birokrasi sudah teratur dengan baik sehingga dapat diketahu dan dipahami apa tugas-tugas yang dilakukan oleh aparatur yang masuk dalam sistem organisasi desa Lowian dan juga dapat diketahui siapa yang dapat bertanggungjawab dalam bidangnya masing-masing, seperti kepala desa yang harus bertanggung jawab kepada masyarakat dan juga kecamatan maesaan atas kegaitan APBDes yang dilakukan oleh pemerintah desa. Sehingga itu dalam struktur birokrasi sudah cukup baik. 


\subsection{Pembahasan}

1. Implementasi Kebijakan Anggaran Pendapatan dan Belanja Desa

Berdasarkan hasil penelitian di atas menunjukan bagaimana implementasi kebijakan dari mekanisme atau alur pengelolaan sampai pada pertanggungjawaban dan juga factorfaktor yang mempengaruhi implementasi kebijakan itu sendiri. Dalam alur pengelolaan sampai pada pertanggungjawaban sebagai berikut; dalam pengelolaan tidak memiliki masalah dan kendala karena dalam hal ini pengelolaan yang dibuat berjalan dengan baik sesuai dengan Peraturan Menteri Dalam Negeri (Permendagri) nomor 113 Tahun 2014. Dalam perencanaan keuangan desa tidak juga memiliki masalah karena keuangan desa lowian sendiri tertata dan terrencana dengan baik. Dalam pelaksanaan pembiayaan belanja desa juga tidak memiliki masalah yang begitu berarti, namun dalam hal pelaporan pertanggungjawaban dalam hal ini APBDes memiliki masalah. Dikarenakan laporan pertanggungjawaban yang masih sering terlambat.

2. Kendala-kendala dalam Implementasi Kebijakan Anggaran Pendapatan dan Belanja Desa

Dalam hal ini yang menjadi kendala yaitu pada sumberdaya manusia yang dikarenakan adanya mekanisme pelaporan seperti hasil penelitian yang cukup sulit untuk dipahami oleh perangkat desa sehingga berdampak langsung pada perangkat desa dimana mereka masih kurang mengerti dan memahami cara pembuatan laporan pertanggungjawaban dikarenakan kualitas sumber daya manusia yang ada didesa umumnya tergolong rendah. Factor pendidikan juga berpengaruh dalam hal ini karena pendidikan dari pada aparatur yang ada ditingkat desa tergolong rendah dan juga kebanyakan hanya mengerti soal perkebunan. Factor usia pada perangkat desa juga menyebabkan masalah karena kurang memahami pengoperasian komputer yang mengakibatkan terlambatnya pembuatan laporan pertanggungjawaban. Kurangnya juga memahami teknis pembuatan laporan pertanggungjawaban oleh apratur desa yang salah satu pendukungnya kurang memahami karena banyaknya uraian kode reking yang harus diingat atau dihafalkan. Tim pemandu penyusunan untuk memandu aparat desa dalam pembuatan laporan pertanggungjawban hanya sedikit dari kecamatan maesaan. Serta factor yang menjadi masalah selain factor-faktor diatas yaitu pelebaran jalan dimana permasalahan terjadi karena banyaknya pohon-pohon yang bertumbuh dipinggir jalan yang dimana pohon tersebut merupakan pohon yang menghasilkan atau menjadi matapencaharian bagi masyarakat seperti cengkeh dan pohon kelapa, dan selain itu tanah-tanah disekitar yang diambil untuk dijadikan jalan merupakan masalah lain dalam mengimplementasikan kebijakan APBDes.

\section{PENUTUP}

\subsection{Kesimpulan}

Berdasarkan hasil pembahasan diatas, maka dapat ditarik kesimpulan sebagai berikut:

1. Implementasi Kebijakan Anggaran Pendapatan dan Belanja Desa (APBDes) di Desa Lowian Kecamatan Maesaan Kabupaten Minahasa Selatan sudah sesuai dengan Peraturan Menteri Nomor 113 Tahun 2014 tentang Pengelolaan Keuangan Desa yang dimana implementasinya sesuai dengan program yang telah ditetapkan.

2. Pengelolaan Keuangan Desa masih memiliki masalah dalam hal kurangannya kapasitas personalia untuk mengelola keuangan desa dan perlunya pengawasan yang lebih untuk mengontrol pelaksanaan keuangan desa.

3. Laporan pertanggungjawab menjadi masalah, dimana sering terlambat diakrenakan hambatan-hambatan seperti kualitas sumber daya manusia yang umumnya tergolong rendah di desa Lowian, factor pendidikan aparatur pemerintah desa yang tergolong rendah karena hanya berlatang belekang pendidikan sebisanya dan juga latar belakang pekerja kebun, factor usia dan perkembangan yang menyebabkan kurang memahami pengoperasian atau penggunaan computer, banyaknya uraian kode rekening yang 
harus diingat/dihafakan yang menjadi salah satu penghambat laporan pertanggungjawaban.

4. Factor-faktor perpohonan dipinggir jalan dan tanah-tanah disekitar yang menjadi masalah dalam melaksanakan kebijakan APBDes itu sendiri.

\subsection{Saran}

Berdasaran kesimpulan diatas, maka penulis dapat memberikan saran sebagai berikut;

1. Mengingat kembali bahwa keberadan program APBDes adalah untuk pemberdayaan masyarakat desa dan juga kamajuan desa, maka diharapkan Dinas PMD selaku pembantu atau perpanjangan tangan bupati dalam pelaksanaan dan pengawasan program ini dapat lebih intensif mengadakan pelatihan terhadap pemerintah dan perangkat desa serta sosialiasi kepada masyarakat tentang pelaksanaan APBDes di desa.

2. Penambahan personalia untuk membantu mengelola keuangan desa dan diharapkan masyarakat desa Lowain untuk dapat berpartisipasi dan mendukung/membantu pelaksanaan kebijakan APBDes agar dapat berjalan dengan baik demi kemajuan desa dan ikut mengawasi pengelolaan keuangan desa.

3. Diharapkan juga peran serta dari Tim Pendamping dari Kecamatan untuk depat selalu membantu perangakat desa terkait pembinaan dan pengawasan dan juga dalam pelaksanaan kebijakan APBDes di Desa Lowian, serta sebaiknya aparatur desa diberi pengetahuan dan pengenalan akan IPTEK dan juga Pendidikan yang lebih baik agar pengetahuan akan pembuatan laporan pertanggungjawaban menjadi lebih baik dan tidak terhambat.

4. Sosialisasi kembali dengan masyarakat akan adanya kebijakan mengenai pelaksanaan APBDes yang dilakukan, dan mencari jalan keluar Bersama masyarakat agar tidak terjadinya suatu kesalah pahaman.

\section{DAFTAR PUSTAKA}

Akib, Haedar. Jurnal Administrasi Publik. Implementasi Kebijakan: Apa, Mengapa dan Bagaimana. Vol 1 No. 1 Tahun 2010. Hal 1-4. Makassar: UNM.

Akonji, D, A, Olubukola, O, A, And Wakili, A, M, 2013. Nexus Between Public Expenditure and Economic Growth By Testing Wangner's Law Time Saries : Evidance From Nigeria. Internasional Jurnal of Development And Sustainability. Vol, 2(4) : 23822395

Dedi, Wiranta, 2012. Akuntansi Sektor Publik, Pengertian Akuntansi Pemerintahan, Pustaka Baru Press.

Hasan 2015. Anggaran Pendapatan dan Belanja Desa, Serial Pengelolaan Keuangan Desa, Mitra Pendukung Desa Lestari.

Nugroho, Riant. 2014. Kebijakan Publik di Negara-negara Berkembang. Jakarta : Pustaka Pelajar.

Pajouw, 2015. Analisi Pencatatan dan Pelaporan Keuangan Pada Unit Pelaksanaan Teknis Dinas Pemerintah Provinsi Sulawesi Utara.

Rohman, Didik Fatkhur. 2013. Implementasi Kebijakan Pelayanan Administrasi Kependudukan Terpadu (Studi pada Dinas Kependudukan dan Catatan Sipil Kota Malang). Jurnal Administrasi Publik (JAP). Vol. 1. Hal. 962-971. Malang. Universitas Brawijaya.

Rondonuwu, 2015. Analisis Efisiensi Dan Efektivitas Pengelolaan Keuangan Daerah Pada Dinas Pendapata Daerah Kabupaten Minahasa. Jurnal Emba Vol. 3 No. 4 Desember 2015. Hal. 23-32. 
Rujiman, Edita Erlina. 2014. Peranan Anggaran Pendapatan dan Belanja Desa Dalam Pembangunan Wilayah Perdesaan Di Kabupaten Serdang Bedagai. Jurnal Ekonom. Vol. 17. Hal 92-102.

Rusmianto Dan Yuliansyah, 2016. Akuntansi Desa, Salemba Empat, Jakarta.

Sadeli, Lili, 2015. Dasar-Dasar Akuntansi. Edisi Pertama, Bumi Aksara Jakarta.

Safwi, I., Sujianto dan Rusly, Z. Jurnal Kebijakan Publik. Implementasi Kebijakan Izin Pemanfaatan Sumber Daya Air. Vol 3 No. 2 Tahun 2010 Hal. 132 Riau : Universitas Riau. 